\title{
Kierkegaard on Truth: One or Many?
}

\begin{abstract}
This paper reexamines Kierkegaard's work with respect to the question whether truth is one or many. I argue that his famous distinction between objective and subjective truth is grounded in a unitary conception of truth as such: truth as self-coincidence. By explaining his use in this context of the term 'redoubling' [Fordoblelse], I show how Kierkegaard can intelligibly maintain that truth is neither one nor many, neither a simple unity nor a complex multiplicity. I further show how these points shed much-needed light on the relationship between objective and subjective truth, conceived not as different kinds or species of truth but as different ways in which truth manifests itself as a standard of success across different contexts of inquiry.
\end{abstract}

Kierkegaard's writings entertain a view according to which truth divides into two: the objective and the subjective. So much is close to the limit of what can be said without controversy about Kierkegaard on truth. Some deny he meant seriously to advance any claims at all about truth. And among those who think he intended a serious distinction between kinds of truth, there is little consensus about how these kinds are to be distinguished and how they are related. In this paper, I propose to reexamine Kierkegaard's ideas about truth with respect to the question whether truth is one or many. That he sharply distinguishes subjective from objective truth may seem to place him directly, and squarely, in the camp that is nowadays called 'alethic pluralism'. I shall argue that this impression is misleading. Kierkegaard's work, I want to show, cuts across debates between monists and pluralists about truth in cogent and interesting ways.

My plan is as follows. I shall begin by providing a close reading of the opening paragraphs of the chapter on truth in Concluding Unscientific Postscript (hereafter, 'Postscript'). My claim shall be that this passage presents an argument for the following conditional: if it is to be conceived substantively, then truth needs to be conceived in a certain, unitary way: viz. truth as 
self-coincidence. I shall characterize truth as self-coincidence as Kierkegaard's core conception of truth; a conception in which the primary candidates for truth are agents, rather than propositions, and which therefore admits an important role for adverbial uses of the so-called truth predicate. By explaining his use in this context of the term 'redoubling' [Fordoblelse], I shall show how Kierkegaard can intelligibly maintain that truth is neither one nor many, neither a simple unity nor a complex multiplicity.

In $\int \ 2$ and 3, I shall turn to the division between objective and subjective truth and explain why I think it is a mistake to construe this distinction, in sortal terms, as one among kinds or species of truth. On the proposal I want to develop, this distinction holds, rather, between ways in which truth manifests itself as a standard of success in different contexts of inquiry. Objectivity, I shall argue, is the way Kierkegaard thinks truth as self-coincidence manifests itself as a norm of empirical inquiry. On this account, aiming for truth in empirical inquiry means trying, so far as possible, to sustain a disinterested perspective on objects in the world, attending only to 'what is there'. Subjectivity, by contrast, is the way Kierkegaard thinks truth manifests itself as a norm of ethical inquiry, broadly construed. On this account, what it is to seek truth in contexts of ethical inquiry is to strive for what I shall call 'agent's-awareness'; that is, trying to fully occupy the first-person perspective of practical agency. Here the aim is to coincide with oneself qua practical agent, through the process Kierkegaard calls 'appropriation'.

I hope in this way to show that objective and subjective truth are not, for Kierkegaard, different kinds of truth but, rather, different ways in which truth manifests itself as a standard of success across different contexts of inquiry. Two important corollaries of the view I shall defend are that, contrary to a common impression, by 'objective truth', Kierkegaard does not mean the set of true propositions (or some member thereof); and that, contrary to another common impression, ‘subjective truth' has nothing especially to do with sincerity, nor any other propositional attitude. 


\section{Truth as self-coincidence: Kierkegaard's core conception of truth}

Expositors of Kierkegaard on truth are naturally drawn to the corpus of his fictional philosopher, Johannes Climacus, and especially to Section Two, Chapter 2, of Concluding Unscientific Postscript; 'Subjective truth, inwardness; truth is subjectivity' (Kierkegaard 1992, p. 189). Critics also tend to skate (or skip) over the opening paragraphs of this chapter, which comprise some compressed remarks of a very general sort about truth. But Climacus' opening remarks are in my view of first importance, not least if we are to properly assess his claim that what he calls subjective truth is, precisely, a matter of truth. Accordingly, my first aim is to work out a closer reading of the first six paragraphs of this chapter of Postscript.

These paragraphs culminate in an enigmatic definition of truth, according to which truth is 'in an entirely abstract sense a redoubling which is nevertheless cancelled at the very same moment' (Kierkegaard 1992, p. 190). How, then, does Climacus arrive at this perplexing definition? He argues, in outline, as follows:

1) Truth is standardly defined as the agreement of thought with being ('the empirical definition') or as the agreement of being with thought ('the idealist definition').

2) If 'being' in these formulas means empirical being then the concept of truth is empty, since thought can never perfectly agree with the empirical reality from which it abstracts.

3) But if 'being' means abstract being then the contrast between the two formulas collapses: nothing can count as bringing thought into agreement with being, nor being with thought, since, abstractly conceived, 'thought and being mean one and the same, and the agreement in question is a mere abstract self-identity' (Kierkegaard 2009, p. 160).

Therefore, if the concept of truth is substantive, then, on either of the standard definitions, truth is merely the 'self-identity' of thought and being. 
What is striking about this overall line of argument is the way it presses the standard definitions of truth towards empty tautology. Any hint of the idea of correspondence in the term 'agreement', for example, is hollowed out as Climacus reduces the traditional formulas to the statement, as he puts it, that 'truth is, with the accent here on the copula - truth is' (Kierkegaard 2009, p. 160). ${ }^{1}$ Climacus' argument here closely tracks one of the sources of Frege's dissatisfaction with any correspondence theory of truth:

A correspondence, moreover, can only be perfect if the corresponding things coincide and so are just not different things. ... It would only be possible to compare an idea with a thing if the thing were an idea too. And then, if the first did correspond perfectly with the second, they would coincide. But this is not at all what people intend when they define truth as the correspondence of an idea with something real. For in this case it is essential precisely that the reality shall be distinct from the idea. But then there can be no complete correspondence, no complete truth. So nothing at all would be true; for what is only half true is untrue. Truth does not admit of more and less. (Frege 1977 [1918], p. 3)

Now, some idealists are prepared to bite Frege's bullet. Thus, Bradley affirmed that nothing is completely true save the Whole Truth About Everything; nonetheless, he thought, common-orgarden judgements are partially true. ${ }^{2}$ But Climacus closes down this route. Like Frege, he assumes that propositional truth is absolute; thoughts can't be partially true. He argues - as per 2 above - that it follows from the (Bradleyan) premise that it is of the nature of thought to abstract from empirical reality that, if truth implies the strict coincidence of thought and empirical reality, then the most truth could amount to is an unattainable desideratum. From this

${ }_{1}^{1}$ Plausibly, Schelling is in the background of Kierkegaard's 'emphasis on the copula'. For a discussion of Schelling on truth and the copula, see Thomas 2014.

${ }^{2}$ Cf. Haak 2005, p. 89 
standpoint, a position like Bradley's collapses into a kind of eliminativism about truth. ${ }^{3}$ If truth is to be given a substantive interpretation, in line with the standard definitions, Climacus thinks we shall need to think in terms of an identity, not between thought and empirical reality but, rather, between thought and abstract being. But that way, he thinks, leads inexorably to the collapse of any genuine contrast between the realist ('empirical') and the idealist definitions of truth.

Climacus' thinking here - as per 3 above - can be reconstructed as follows. There can be a genuine contrast between the two traditional definitions of truth only if thought and being can stand in a relationship of priority, one way or the other. On the realist's formula, it is being that is supposed to have the priority. The pursuit of truth, accordingly, is the aim to bring our representations into conformity with the ways things are. On the idealist's definition, by contrast, the priority is given to thought. Here, the pursuit of truth is the aim to render being intelligible in the form of a coherent system of thought. But now comes the difficulty. For if we conceive of being in an abstract enough way, so that it can truly coincide with thought, then neither of these priorities is coherent. To illustrate: suppose we conceive of thought, in abstracto, as the ways the world is intelligibly said or thought to be. And suppose we conceive of being, in abstracto, as the world as it is intelligibly said or thought to be. Then clearly there can be no question of a relation of priority here, since now, as Climacus observes, 'thought and being mean one and the same' (Kierkegaard 2009, p. 160); indeed, for this reason, there can be no question of a relation at all. After all, we could refer to the concept of the ways the world is intelligibly said or thought to be by a single term: Heraclitus' 'logos', perhaps, or McDowell's 'thinkables'. ${ }^{4}$ But then the contrast

\footnotetext{
${ }^{3}$ That his so-called identity theory of truth ultimately turns out to be eliminativist is already suggested by Bradley's famous talk of a 'happy suicide' of thought. As Candlish and Damnjanovic observe: ' $[\mathrm{t}] \mathrm{alk}$ of an identity theory of truth ... is ultimately misleading in application to Bradley, since his theory ends up as eliminativist: on his anti-Hegelian view, reality transcends the rational and turns out not to have a fact-like structure expressible in any propositional form at all, so that when full truth is attained, the point of inexpressibility is reached. Thus Bradley, despite using the word 'identity' to describe his view, says as well that 'in the proper sense of thought, thought and fact are not the same' and talked of the attainment of truth in terms of thought's 'happy suicide" (Candlish \& Damnjanovic 2007: 240).

${ }^{4}$ For McDowell's own version of an identity theory of truth, which makes reference to 'thinkables', see McDowell 2005.
} 
between the two formulas collapses and we are left with the mere idea of an identity of thought and being. ${ }^{5}$

Climacus concludes on this basis that, if the traditional formulas point to a substantive definition of truth, this must be that truth is the identity of thought and abstract being. What, then, does it mean to define truth in this way? As we have indicated, Climacus quickly goes on to give this definition a surprising gloss, in terms of the idea of a 'redoubling' or 'duplication' [Fordoblelse]. It is here that Climacus' exposition is at its most perplexing. But, as I hope to show, it is also just at this point that he offers a distinctive general account of the nature of truth. The crucial passage is this:

But if being is understood in this way [sc. not as empirical being but abstractly], the formula [sc. that truth is the agreement of thought with being] is a tautology; that is, thought and being mean one and the same, and the agreement in question is merely an abstract selfidentity. So neither formula [sc. neither the 'empirical' nor the 'idealist' definitions of truth] says more than that truth is, with the accent here on the copula: truth is, i.e., truth is twofold ['truth is a redoubling']. Truth is the first, but truth's second, that it is, is the same as the first; this latter, its being, is truth's abstract form. This is a way of saying that truth is not something simple but in an entirely abstract sense a duplication which, however, is in the same instant cancelled ['truth is a redoubling, which is nevertheless cancelled at the very same moment']. $\left(\right.$ Kierkegaard 2009, p. 160) ${ }^{6}$

\footnotetext{
${ }^{5}$ Compare Parmenides' Fragment 3: 'because the same thing is there for thinking and for being' (Gallop 1984: 56-57).

${ }^{6}$ The alternative translations, given in square brackets, are the Hongs' (Kierkegaard 1992, p. 190). Hereafter, all references to Postscript are to Hannay's translation (Kierkegaard 2009). This translation is forcefully defended, with special reference to passages on truth, in Possen 2010. I note the Hongs' alternatives here, however, because they use the same English word, 'redoubling', to translate both instances of the Danish term 'Fordoblelse' in this passage; and because, in my view, this more established translation of the term better brings out the ideas of reflexivity and self-coincidence which, as I shall argue, are central to Climacus' use of it.
} 
Climacus' first emphasis here is on the uninformative character of the traditional definitions of truth. And he is in general wont to complain that, because they never really get beyond tautology, philosophical discussions of truth all too quickly become sterile. However, this note of impatience with efforts to define truth is evidently far from the whole story about Climacus. For, he appears to have in mind a quite particular conception of what it means to define truth as the identity of thought and being; one from which he thinks it follows that truth is 'not something simple' but is, rather, a 'redoubling' or 'duplication' [Fordoblelse].

We can gain traction on this difficult train of thought, I suggest, if we associate the idea of the self-identity of thought and being with the concept of God. (Note that, according to Climacus' argument, this is plainly not to conceive of the divine mind, in panentheistic fashion, as identical with empirical reality). This suggestion is in fact directly supported by the text: Climacus goes on to remark that the self-identity of thought and being is actual, 'in the case of God' (Kierkegaard 2009, p. 160). More precisely, I suggest that the notion of 'redoubling' is intended to make a connection between truth and a certain form of agency, viz. divine agency. The connection is that divine agency, conceived as 'redoubling', paradigmatically exemplifies truth, conceived as the 'self-identity of thought and being'. Further, indirect, support for this suggestion is provided by a journal entry in which Kierkegaard moots a rather abstract definition of God as 'infinite redoubling. ${ }^{8}$ On Kierkegaard's understanding, there is within divine agency an in-built duality, between God's self-awareness and God's being, notwithstanding their perfect agreement. And this, I take it, is what Climacus has in mind, too, when, using the idea of divine agency as the paradigm, he avers that truth is a 'redoubling, which is nevertheless cancelled in the very same moment'.

\footnotetext{
${ }^{7}$ On antecedents of Kierkegaard's conception of truth as redoubling in Fichte, see Kangas 2007, p. 80.

${ }^{8}$ Kierkegaard writes: '[God] has not an element of objectivity in his being ... but God relates himself objectively to his own subjectivity, but this again is simply a redoubling of his subjectivity ... God is infinite redoubling' (Kierkegaard 1976, 4571 / XI 2 A 97).
} 
I therefore propose the following interpretation of Climacus' enigmatic gloss on the traditional definitions of truth. He holds that, if it is to be substantive, the concept of truth must apply, paradigmatically, to a certain form of agency. This is, namely, a form of agency that satisfies two conditions: (i) it must exhibit the duality of self-relation; and (ii) it must remain in agreement with itself, being in no wise self-estranged. A form of agency that perfectly satisfied both of these conditions would be neither a simple unity, since it would exhibit the duality of self-relation, nor a complex multiplicity, since it would also exhibit perfect self-coincidence. It is in this sense that truth is said, no doubt picturesquely, to continually bifurcate only to immediately collapse back into itself. More prosaically, we can say that what Climacus is working out here is a conception of truth as self-coincidence. On Kierkegaard's understanding, God is the very archetype of truth as self-coincidence. Divine agency is Truth itself; there is in God no opacity, duplicity or shadow of turning: 'I am that I am' (Exodus 3:14). (Compare Shakespeare's Iago: 'I am not what I am' (Othello, Act I, Scene I, line 66)).

How, then, does Climacus get from the idea of an identity of thought and being to these ideas of redoubling and divine agency? What is doing the work here, I suggest, is his aim of salvaging something from the idea of agreement in the traditional definitions of truth. As we have seen, Climacus thinks the idea of agreement cannot be cashed out in either of the ways envisaged by realists and idealists. Nonetheless, he thinks we can still attach genuine significance to the idea of truth as agreement if we conceive of truth, not merely as an immediate identity or unity - the unity of the intelligible structure of reality, say - but rather as a reflexive form of agreement, a form of self-identity in which reality coincides with itself. And he thinks that, if anything perfectly exemplifies a reflexive form of agreement, this is divine agency.

Climacus' reasoning can therefore be summarized as follows. In the end, neither the idealist nor the realist definitions of truth say more than that truth is the identity of thought and being. Uninformative though it seems to be, there is nonetheless a way to interpret this formula as a substantive definition of truth. On this interpretation, the formula applies, in the first 
instance and paradigmatically, to God; that is, to God qua perfectly self-coinciding agent. It is no doubt a further question whether this ontologically committed interpretation of truth can be defended, for example against deflationary or eliminativist accounts. Climacus offers no such defence. His conclusion is best viewed as a conditional: if it can be given a substantive interpretation, then truth must be interpreted by reference to God qua perfectly self-coinciding agent.

Does this mean Climacus thinks of divine agency as just one way in which the definition of truth is satisfied? On the contrary, he evidently holds that the ideas of agency and redoubling are apt to define truth as such. For, as we shall see, he directly goes on to ask how, understood in this same way, truth could apply to finite agents like us. There must therefore be more to his claim that God exemplifies truth than that God is one example among others. It is notable in this connection that Climacus' discussion has antecedents in scholastic discussions of the place of truth in the so-called 'doctrine of transcendentals': viz. the theory of that which, being expressed in everything, cannot be tied to genera, species or created individuals. ${ }^{9}$ In this tradition, to predicate truth (or being, or unity, or goodness) of God is not merely to say that God instantiates this property; on the contrary, in Aristotelian terms, theological applications of the transcategoricals have a special role in supplying their 'focal meaning'. Plausibly, it is against this background that Climacus thinks he can derive a general conception of truth from his claim that, qua 'infinite redoubling', God exemplifies truth..$^{10}$

\footnotetext{
9 According to this tradition, truth, no less than Aristotle's being, is said in many ways but cannot be carved up into kinds. With reference to Albert the Great, Jan Aetsen sums up the trend of scholastic thought in this regard: 'Albert's strategy in his reply [to Aristotle] consists in emphasizing the multiplicity of the term 'true': it is said in many ways (multipliciter dictur). He makes a distinction between a general (ontological) sense of truth and a special (logical) sense: "Truth" can signify a general disposition of being or a composition of terms in the intellect. This distinction is typical of the medieval reception of the Aristotelian conception of truth and is also invoked by Duns Scotus in his Metaphysics commentary. Truth, he observes, is two-fold: there is not only truth in the intellect but also in things' (Aertsen 2012, pp. 6566).

10 Through his close readings of Baader on Eckhart and Baur on Scotus, Kierkegaard was no doubt familiar with scholastic discussion of truth as transcendental, i.e. transcategorical. It is in this tradition that Eckhart can write: 'Those properties which are God's own are Being or being, Unity, Truth, Goodness. For God has these four transcendental as properties in as much as $<\mathrm{God}>$ is 'the first', which is 'rich in
} 
Now, Climacus is in a hurry to move on to the question of what, since we are not God, truth as self-coincidence could possibly mean for finite beings like us. As we shall see (in $\$ 2$ below), it is precisely in response to this question that he introduces his distinction between objective and subjective truth. But let me pause to draw out three features of the core conception of truth that I think we may plausibly associate with Kierkegaard, viz. truth as selfcoincidence.

Firstly, this conception plainly relies on there being candidates for truth other than judgements, statements or propositions. Kierkegaard apparently thinks the primary truth-bearers are agents: paradigmatically, God. Now, from the perspective of contemporary philosophy of language, at least, the idea of non-propositional candidates for truth must no doubt seem strange and suspicious. In Kierkegaard's own milieu, however, Hegel had clearly articulated a view in which truth is not solely, nor even primarily, a matter of the correctness of judgements:

Truth is at first taken to mean that I know how something is. This is truth, however, only in reference to consciousness; it is formal truth, bare correctness. Truth in the deeper sense consists in the identity between objectivity and the notion [Begriff]. It is in this deeper sense of truth that we speak of a true state, or of a true work of art. The objects are true, if they are as they ought to be, i.e. if their reality conforms to their notion. (Hegel 1975, p. 276)

As Robert Stern has noted, Hegel here anticipates Heidegger's contrast between propositional and material truth (Stern 1993, p. 645ff). Under the material conception, 'true' is a noun-qualifier, where for some $\mathrm{X}$ and for some F, $\mathrm{X}$ is a true F; as when we speak of a true friend who shows true grit. ${ }^{11}$ Heidegger's favourite example is 'true gold', in contrast with the bogus stuff that

itself. God has these because the rich in itself has that which is proper to itself (cited in Hackett 2013, p. 188). On the Eckhartian provenance of Kierkegaard's conception of divine 'redoubling', see Kangas 1998.

${ }^{11}$ Cf. Barnes 2011, p. 95. 
merely passes itself off as gold. ${ }^{12}$ Crucially, however, while such examples may help to bring into view the general idea of a material (or 'objectual') use of term 'true', it is plausibly only in a derivative sense that inanimate stuff like gold and iron pyrite can be called 'true' and 'false'. At any rate, Kierkegaard, for his part, clearly conceives of the archetype of material truth, rather, as the self-coinciding agent. (Indeed, it is plausible that when we say e.g. that pyrite 'passes itself off as gold we are metaphorically extending a notion of agency to the pyrite; and we say 'fool's gold' as well as 'false gold'. ${ }^{13}$ )

Does Kierkegaard then at all allow for propositional truth? I shall not attempt here a full answer to this important question and it has to be admitted that he says little to address it. However, the following points are preliminary to an answer. First, there is in Climacus' discussion no hint of an attempt to reduce the truth-conditions of judgements to justification or assertability-conditions. On the contrary, he refers to tokens of the statement that the earth is round, for instance, as straightforwardly true. Second, it may be open to Kierkegaard to hold, along the lines of Aristotle's so-called theory of focal meaning, that, while truth as selfcoincidence captures its focal meaning, truth can nonetheless be said in many ways. Accordingly, he may hold that propositions are properly said to be the kind of thing that can be true or false in a way that is secondary with respect to the way agents can coincide or fail to coincide with themselves. And third, we should note that Kierkegaard may hold that there is nothing much to be said about the nature of propositional truth. If anything, Climacus' emphasis on the tautological character of the traditional definitions supports a view of propositional truth that is modest if not deflationary. ${ }^{14}$ Indeed, by the argument outlined above, if propositional truth is all

\footnotetext{
12 Thus, Heidegger: 'the word 'true' is ambiguous ... used of things (true gold) and of sentences (true propositions), whereby the prevailing view is that 'true' and 'truth' apply in the first place and originally to propositions' (Heidegger 2002, p. 86).

${ }^{13}$ Because of the way it ties truth to agency, Kierkegaard's non-propositional view is notably immune to certain familiar objections to Heidegger's own non-propositional account of truth as the 'beinguncovered' of an entity. For a classic critique of Heidegger on this score, see Tugendhat 1993.

${ }^{14}$ Compare, e. g., Wolfgang Künne's 'modest, or quantificational account' of truth (Künne 2008), which develops Wittgenstein's formula: 'what he says is true = things are as he says' (Wittgenstein 1974, p. 123).
} 
there is to truth then, properly thought through, the traditional definitions lead to empty tautology. ${ }^{15}$

A second feature of truth as self-coincidence is the way it construes the so-called truth predicate. As we have just emphasized, Kierkegaard's view admits of agents as candidates for truth, with respect to the ways they exercise their agency. ${ }^{16}$ Accordingly, I think it best fits with his view to construe the so-called truth predicate as most fundamentally playing an adverbial role. On this account, an agent is 'in the truth' - or, as we may also put it, she comports herself trulyjust to the extent to which she exercises her agency in a self-coinciding way. Conversely, you are 'in untruth' - you comport yourself untruly - just to the extent to which you are characterized by self-division, duplicity, self-estrangement. ${ }^{17}$

A third feature of truth as self-coincidence is that it admits of degrees. Again, this is not to say that Climacus countenances degrees of propositional truth. He is not, I think, vulnerable to the charge, sometimes leveled against Bradley, of inferring fallaciously from ' $p$ is only part of the truth' to 'p is only partially true'. ${ }^{18}$ Rather, the relevant idea is that the degree to which a given agent is 'in the truth' - the degree to which she comports herself truly - is the degree to which she self-coincides in the exercise of her agency: the less self-estrangement, the more truth.

${ }^{15}$ Note also in this connection that Climacus' argument is conditional on two undischarged assumptions: that (i) the traditional definitions point, albeit inadequately, to something important about truth; and that (ii) truth can be given a substantive interpretation.

${ }^{16}$ Because it does not conceive of propositions as the primary bearers of truth, Kierkegaard's view escapes the problem, faced by identity theory of truth of the propositional sort, of seeming to need to posit false states of affairs that are identical with false judgements.

${ }^{17}$ An immediate worry here is that these criteria may be too permissive to plausibly count as criterial for adverbial truth / untruth. A full appraisal of Kierkegaard's thought on this score would need to take a wider view than the claims he attributes to Climacus. It would need to encompass, not least, 'An Occasional Discourse', in which Kierkegaard argues that 'purity of heart is to will one thing' but that, crucially, only the good turns out to be 'one thing' in the relevant way (Kierkegaard 1993, p. 24ff). Notably, Kierkegaard's ethically thick notions of 'purity of heart' and 'double-mindedness' therefore appear to go beyond Climacus' comparatively thin, procedural account of the contrast between exercising one's agency truly and untruly. I shall consider the way that Climacus applies his account to ethical inquiry, in \$3 below. I leave for another occasion the task of a wider assessment of Kierkegaard on truth in the light of the worry that Climacus' account is too 'thin' in this regard. My thanks to an anonymous referee for this journal for drawing to my attention the importance in this connection of the question of the relationship between Climacus and the author of 'An Occasional Discourse'.

${ }^{18}$ For an instance of this criticism of Bradley, see Haack 2005, p. 100. 
Criteria for judging how far an agent's conduct self-coincides will vary according to context of assessment, as I shall argue below.

So does Kierkegaard think truth is one or many? So far, we have seen that Postscript articulates a unitary, substantive account of truth: truth as self-coincidence. This already sets Kierkegaard apart from any form of alethic pluralism that rejects the very possibility of a unitary, substantive definition of truth. However, we have also seen that, according to truth as selfcoincidence, truth itself is neither a simple unity nor a complex multiplicity. It follows from the reflexivity built into the idea of self-coincidence that truth is not a simple unity: for, it is of the nature of truth to double back on itself, bifurcating into subject and object. On the other hand, it follows from the idea of self-coincidence that no duplicity or two-sidedness is established by the duality of the self-relating agent. There is therefore an intelligible way for Kierkegaard to maintain that truth is neither one nor many, neither a simple unity nor a complex multiplicity. In a slogan: truth is dual without being double. ${ }^{19}$

What remains to be seen is how we are to understand the relationship between truth as self-coincidence and Kierkegaard's division between objective and subjective truth. In turning to this issue, my aim now is to show how these two 'kinds' of truth are not really kinds at all; rather, they are different ways in which truth manifests itself as a standard of success across different contexts of inquiry. It is also part of my aim to begin to spell out what 'self-coincidence' might mean in these contexts.

\section{Objective truth as one manifestation of truth as self-coincidence}

Kierkegaard is often said to have held that there are two kinds of truth. Thus, in her recent book, Ways of Knowing: Kierkegaard's Pluralist Epistemology, M. G. Piety declares that 'Kierkegaard was clearly aware ... that his views supported the view that there were two kinds of

${ }_{19}$ Thanks to David McNeill, who suggested this formulation to me. 
truth' (Piety 2010, p. 48). Likewise, Arnold B. Come sums up as follows a view of Kierkegaard that is orthodox to the point of being platitudinous:

According to Kierkegaard, human thinking works in two different ways ... He calls them 'objective reflection' and 'subjective reflection.' Each produces a different kind of 'truth', both of which are valid and useful within certain limits. (Come 1995, p. 85) ${ }^{20}$

Come's shudder-quotes around 'truth' seem to betray some uneasiness on his part with the idea that there might really be different kinds of truth. But did Kierkegaard really think that there are? One thing that should immediately give us pause is simply that the language of 'kinds', 'species', 'types', 'sorts', or even 'modes' or 'forms' of truth is nowhere to be found in, for example, the chapter on truth in Postscript. ${ }^{21}$ Instead, Climacus writes there, with respect to his contrast between two general contexts of thinking and inquiry, of truth's becoming different, across the two contexts. So we should ask whether there might not be some significance in these striking locutions about truth's ways of 'becoming'.

How, then, does Kierkegaard distinguish between objective and subjective truth? In Postscript, the distinction makes its entry as follows:

When the question of truth is raised by an existing spirit, qua existing, that abstract duplication recurs. But existence itself, existence in the questioner, who does indeed exist, holds the two factors apart, and reflection marks out the two relations. For objective reflection the truth becomes something objective, an object, and the thing is to disregard the subject. For subjective reflection the truth becomes appropriation, inwardness, subjectivity,

\footnotetext{
${ }^{20}$ Examples are readily multiplied. Unguarded references to Kierkegaard's division between objectivity and subjectivity as a distinction among kinds or sorts of truth include Pojman 1984, p. 73; Solomon 1987, p. 77; Rae 1997, p. 146; Walsh 1997, p. 272.

${ }^{21} \mathrm{~A}$ further reason to pause is the point already noted above regarding the antecedents of Kierkegaard's thought in scholastic discussions of truth.
} 
and the thing is precisely, in existing, to deepen oneself in subjectivity. (Kierkegaard 2009, p.

As befits the way in which the idea of agency enters into his core view of truth, what Climacus means by 'the question of truth' here is evidently the question: what does it mean for beings like us to exemplify truth? Above all, he wants to combat any tendency we may have in this regard to confuse ourselves with God. We finite subjects cannot exemplify truth in the way God does. To be sure, as agents or 'spirits' we, too, are characterized by the duality of self-relation. That we exist within a nexus of historical and empirical becoming, however, is itself sufficient to 'hold apart the two factors' - viz. thought and being - so that, for us, the pressing question is how the two can be brought together.

It is by way of an answer to this question that Climacus distinguishes two corresponding 'paths' of reflection and inquiry. The one path takes up the task of making manifest the empirical world. This way leads to natural science, to 'abstract thinking, to mathematics, to historical knowledge of various kinds' (Kierkegaard 2009, p. 163). The other path takes up the task of trying to become manifest to oneself qua self-relating agent. This way leads to 'appropriation' and to ethical and religious forms of self-understanding in the context of inquiry into the human good. Now, in my view, these two contexts of inquiry are by no means supposed to 'produce two kinds of "truth". I hope to show that, on the contrary, Climacus thinks that a single idea of truth - truth as self-coincidence - manifests itself in different ways as a norm of inquiry in these two contexts.

Consider first the case of 'objective truth'. Climacus says that, from the perspective of objective reflection, 'truth becomes something objective, an object' (Kierkegaard 2009, p. 161). In empirical inquiry, the goal is to achieve impersonal knowledge of objects in the world, knowledge of 'what is there' [Tilvaerende]. Negatively put, the goal is to purify one's perspective from any distortion or restriction that arises from any special interest one may have in one's own 
existence. ${ }^{22}$ Climacus is quick to point out that there is something ultimately paradoxical about this goal, inasmuch as it leads 'at its maximum' to 'a contradiction' (Kierkegaard 2009, p. 163), viz. the idea of a perspective-free perspective, a 'view from nowhere' in Nagel's famous phrase. As situated, finite beings we can, Climacus insists, only ever approximate to a purely objective perspective. But he is also at some pains to emphasize that attending solely to 'what is there', so far as is humanly possible, is an important part of what it means for beings like us to seriously pursue the truth.

Now, one might naturally complain that the ideal of objectivity has nothing especially to do with self-coincidence and so a fortiori cannot be the way truth as self-coincidence manifests itself as a norm of empirical inquiry. We can make sense of Climacus' view, however, if we allow that part of what it is to aim for objectivity is in general to try to sustain a certain stance towards oneself, qua object among objects in the empirical world. In Climacus' terms, the required stance is one of disinterestedness. Recall in this connection, for example, Bacon's doctrine of the idols of the mind:

For the mind of man is far from the nature of a clear and equal glass, wherein the beams of things should reflect according to their true incidence, nay, it is rather like an enchanted glass, full of superstition and imposture, if it be not delivered and reduced. For this purpose, let us consider the false appearances that are imposed on us by the general nature of the mind.

(Bacon 2011 [1861], p. 276)

In this passage, Bacon is clearly thinking of himself in a quite particular way, as an object among objects, part of the causal nexus. In short, he exemplifies the type of self-awareness Kant called

22 Cf. Tacitus' pledge to relate history sine ira et studio, without passion or partiality. Cf. also Nicholas Rescher on the ideal of objectivity: 'We try, in short, to free what we maintain from our personal idiosyncrasies: from biases, idiosyncrasies, predilections, personal allegiances, and the like' (Rescher 1997, p. 6). 
empirical. No doubt Bacon has his own (empiricist) view of what objectivity and disinterestedness ultimately involves; one whose details we should not ascribe to Kierkegaard. Nonetheless, it is clear that, in Climacus' view also, aiming for objective truth quite generally means striving to sustain the third-person perspective of empirical self-consciousness: regarding one's own reality, as it were, from the point of view of the universe.

In what sense, then, does objectivity manifest an ideal of self-coincidence? Consider a case of scientific misconduct of a familiar sort. A paper in The Lancet in 1998 purported to establish a link between the MMR vaccine and autism. It subsequently emerged that twelve of the children in the study were recruited via a UK lawyer preparing a lawsuit against MMR manufacturers and, moreover, that one of its authors received a large sum in undisclosed fees two years prior to publication. It is plausible, to say the least, that this conflict of interest vitiated this author's posture of objectivity: his personal investment meant that he failed to coincide with himself merely qua object among objects in the empirical world. He became self-divided, doubleminded, duplicitous. In the title phrase of a classic work on scientific fraud, he took his place among the 'betrayers of the truth' (Broad \& Wade 1982).

Still, it might be objected that the pursuit of objective truth involves trying to achieve self-coincidence, if it involves this at all, only as means to end. Is not the goal of such inquiry simply to state truths about the world? Now, if we have in mind specific domains of research the investigation of black holes, say, or the history of twelfth century heresy - I do not think Climacus means to deny that the proximal goal of such research is just to find out more about black holes or heretics. What he denies, rather, is that the human pursuit of objective truth can in general be reduced to the aim to utter correct statements about the world. As his parable about the truth-telling lunatic helps to show - in which a man escaped from the asylum tries to prove his sanity by periodically blurting out that the earth is round - the mere aim to utter truths about the world is compatible with all sorts of madness (Kierkegaard 2009, pp. 163-4). 
It is also salutary that the claim that objectivity is how truth as self-coincidence manifests itself as a norm of empirical inquiry is not the claim that the ideal of self-coincidence must enter into the minds of empirical inquirers as their explicit guide and goal. Climacus' idea is not, implausibly, that if you ask a natural scientist or historian what they are aiming for they will likely tell you they are aiming to self-coincide. On the contrary, his account predicts they will say they are aiming for objective truth. For the claim is, precisely, that it is in the form of objectivity that truth manifests itself as a standard of success within these contexts of inquiry.

So Climacus may with some plausibility conceive of objective truth as the distinctive way that truth as self-coincidence manifests itself as a norm of empirical inquiry. In this arena, we can say that, for Climacus, an inquirer is 'in the truth' - she comports herself truly - just to the (limited) extent to which, in whatever particular researches she undertakes, she is able to sustain a disinterested point of view on the objects of her research. Notably, Climacus is even given to present the kind of self-transformation this involves as a kind of spiritual exercise, a 'dying to self by detaching from any special interest one may have in one's own existence, concentrating one's attention solely on 'what is there..23

If this interpretation is right, it follows that by 'objective truth' Climacus does not mean propositional truth. He means, rather, the way truth as self-coincidence manifests itself as a norm of objective inquiry. Accordingly, with regard to his undeniable stress on the limits of objectivity, we need to keep separate the following two claims:

A. It is impossible for abstract thought to perfectly coincide with empirical reality.

B. It is impossible for human beings to fully realize the goal of objective truth.

${ }^{23}$ Cf. Simone Weil's conception of what is required by 'attention': 'suspending our thought, leaving it detached, empty and ready to be penetrated by the object' (Weil 2010, p. 35). 
We have seen that Climacus endorses both of these claims, A and B. But, as we have also seen, Climacus is not Bradley: he does not infer from A that the propositional contents of our judgements can only ever be partially true. Rather, he concludes that truth is not merely propositional. And it is on the basis of his fundamentally non-propositional conception of truth - truth as self-coincidence - that he further concludes that (B) it is impossible for us to fully exemplify objective truth qua way of being human.

These points give the lie to a more common picture of Kierkegaard on truth. On this picture, his idea of 'objective truth' is more or less straightforward: it is simply the idea of (some member of) the set of true propositions. But, on this picture, Kierkegaard is like Bradley: he thinks we finite thinkers can only ever grasp partial truths about the reality from which it is of the nature of our thoughts to abstract. The more distinctive - for many, wildly implausible - part of his view is then the idea that there is a quite different species of truth, called 'subjective truth', which has something to do with the subject's attitude towards her reflectively endorsed beliefs, whether she holds these beliefs sincerely enough, perhaps, or with enough gusto. But we have seen that Kierkegaard's idea of 'objective truth' is not equivalent to the idea of true propositions. On the contrary, he works with a different conception of objective truth, as a standard of inquiry in which inquirers approximate to the ideal of a perfectly disinterested view on empirical reality, not least their own.

In what follows, I hope to make it plausible that Kierkegaard conceives of subjective truth, not as a different kind or species of truth, but as a different way that truth as selfcoincidence can manifest itself as a norm of inquiry. If I am right, 'subjective truth' has nothing especially to do with sincere belief, nor any other propositional attitude.

\section{Subjective truth as another manifestation of truth as self-coincidence}


We have seen that Climacus thinks it is not for us to manifest the perfect selfcoincidence of divine 'redoubling'. And we have seen that he thinks one way for us to take up the pursuit of truth is through objective inquiry, where the aim is to take up a disinterested perspective on empirical reality. But this is not all. For, Climacus' emphasis is famously on a different way for us to take up the pursuit of truth, which he describes variously as 'subjective thinking', 'subjective reflection' and 'double-reflection'. Why, then, is the idea of objectivity inadequate, by itself at any rate, to specify what it means for finite beings like us to pursue truth? Plausibly, Climacus' discussion turns at this point on the following thesis:

(Objective Opacity): Relating to oneself merely as an object among objects is itself a form of self-estrangement.

At the heart of Climacus' thought is the idea that human beings are not just numerically distinct objects in the world but self-relating agents, ineluctably characterized by a first-person perspective and confronted by the issue how to live. We are not God; but we nonetheless share in the duality of subjectivity and self-relation. Accordingly, Objective Opacity implies that human subjectivity is not exhausted by empirical self-consciousness. On a familiar, Kantian line of argument, human subjectivity cannot be exhausted by empirical self-consciousness since the standpoint of practical agency cannot be objectified. I shall not try to defend Objective Opacity here. Rather, my aim in the remainder of this essay is to make it initially plausible that 'subjective truth' is the way Kierkegaard thinks self-coincidence manifests itself as a norm of ethical inquiry, broadly conceived; that is, in the context of questions about the human good and how to live.

As we have noted, Postscript introduces 'subjective truth' as what truth 'becomes', from the perspective of a certain sort of thinking and inquiry. For subjective reflection, 'truth becomes appropriation'. And, as he goes on to make clear, subjective reflection is the 'path' of inquiry Climacus deems appropriate to contexts of what he calls 'ethical and ethico-religious knowing' 
(Kierkegaard 2009, p. 166). So his basic claim is that aiming for truth, with respect to ethical and religious questions, means aiming for 'appropriation'. Any adequate interpretation of Climacus on subjective truth therefore needs to explain how he thinks 'appropriation' can furnish a standard of success for ethical inquiry; one, moreover, that is robust enough to constitute a norm of truth. In working towards an interpretation that meets this basic condition of adequacy, let me first identify two approaches that I think signally fail to meet it.

On one approach, appropriation is a qualification of the propositional attitude of belief, closely related if not identical to sincerity. Roughly, the idea is that I 'appropriate' the belief that $\mathrm{p}$ just in case I am sincere or unreserved in my belief that $\mathrm{p} .{ }^{24}$ But the obvious rejoinder is that the mere injunction to be sincere is far too weak to be a standard of ethical truth: one need only mention 'the sincere Nazi ${ }^{25}$ And two textual points tell decisively against the only-be-sincere reading of Kierkegaard. For one thing, to make sincerity either necessary or sufficient for subjective truth sits uneasily with Climacus' central appeal to Socrates, as a paradigm of both existential irony and subjective truth. But further, in his 'Conclusion', Climacus explicitly distinguishes his own conception of 'appropriation' from any mere idea of strong commitment to a doctrine. As Climacus rightly observes, if what we mean by 'appropriation' is just this - a person's sincere, unswerving commitment to a given doctrine - then one mode of appropriation can only be distinguished from another by reference to the doctrines themselves: as he says, 'one must again resort to the 'what', which is the doctrine' (Kierkegaard 2009, p. 512). By contrast, Climacus contends that what he calls 'the pathos of appropriation' is radically dissociable from propositions, theses, doctrines and the like (idem).

On a second inadequate approach, appropriation means: putting into practice. Accordingly, I 'appropriate' the belief that $\mathrm{p}$ just in case I put the belief that $\mathrm{p}$ into practice and 'live it out'. Now, it is certainly part of Climacus' view that, in ethical inquiry, one's attention needs to be

${ }^{24}$ Thus, Louis Pojman: 'We see, then, that this concept of subjectivity has to do with a relationship to one's beliefs' (Pojman 1983, p. 67)

${ }^{25}$ Cf. Evans 1998, p. 171ff. 
directed not only towards theoretical issues regarding what to think about the human good but also, and with the sharper focus, on how one is actually living. But, again, it appears that the mere injunction to practice what you preach cannot play the role of a standard of truth. For much surely depends on what you preach. It is hardly charitable to ascribe to Climacus the view that a preacher of self-deception, for example, turns out to be a paradigm of 'subjective truth', just so far as he or she manages to actually live out a self-deceived life.

The idea that Kierkegaard thinks sincere conviction is sufficient for a 'kind' of truth has led many critics to worry about the threats of subjectivism and relativism. But these worries, I submit, stem from our tendency to impose on him an alien framework in which the only notions relevant to the analysis of truth are those of mental content, beliefs, propositional attitudes and the like. On the alternative proposal I want to canvass, 'appropriation' is best understood as the way Kierkegaard thinks self-coincidence manifests itself as a standard of success in ethical inquiry. Specifically, I think we may ascribe to him the view that aiming for truth in ethical contexts means measuring oneself against what we might call 'the agent's-awareness test': to what extent do you properly occupy the first-person perspective of practical agency? On this proposal, how well you score against the agent's-awareness test, with respect to a given ethical question, is the extent to which you exemplify subjective truth with respect to that question.

What, then, is agent's-awareness? Lucy O’Brien has advanced the following thesis: ' $A$ subject being aware of her action is constituted by the action being the product of the subject's consideration of possibilities, grasped as possibilities' (O’Brien 2007: 120, her italics). The core suggestion here is that the idea of a kind of self-awareness is built into the very idea of a subject's 'active consideration' of possibilities for action, since this requires an agent's regarding these as possibilities 'for her' (O’Brien 2007: 117). I submit that O'Brien's 'Constitution Thesis for Agent's Awareness' is apt to capture a central theme in Kierkegaard's thought. In Postscript, for instance, Climacus remarks on the relationship between thought and action as follows: 
If there is to be any distinction at all between thought and action, this can only be sustained by assigning possibility, disinterestedness, and objectivity to thinking - action to subjectivity. But now a confinium readily comes in sight. Thus, when thinking that I want to do such and such, this thought is not yet an action and differs in all eternity from it qualitatively, but it is a possibility in which the interest of action and actuality is already reflected. Disinterestedness and objectivity are therefore about to be disturbed because actuality wants to come to grips with them. (Kierkegaard 2009, p. 284)

If there is a genuine contrast between thought and action, Climacus suggests, this can only be because of thought's constitutive role in disinterested, objective inquiry. But he insists nonetheless on there being a kind of thinking that occupies the border-zone, as it were, between thought and action, so conceived, in which the attitude of disinterested contemplation is disturbed. This is the grasp of possibilities for action as possibilities for me. It is thinking, as Climacus puts it, in which 'the interest of action and actuality is already reflected'.

Now, on the interpretation we are considering, Kierkegaard holds that agent's-awareness, as built into the active consideration of possibilities for action, is a requirement of genuine ethical inquiry, broadly conceived. More: he holds that agent's-awareness is what truth 'becomes' in this context of inquiry. ${ }^{26}$ And my proposal is that what it means to treat agent's-awareness as a standard of success in ethical inquiry is to assess how far one's ethical thinking and practice is informed by one's awareness of the issues at stake as issues 'for me' (i. e. 'the agent's-awareness test'). A full development of this proposal is beyond the scope of this essay. But we can begin to spell it out with reference to Climacus' notorious thought-experiment involving two people praying. The crux is this:

\footnotetext{
${ }^{26}$ We may recall in this connection the young Kierkegaard's Gilleleje journal, in which he famously sets himself the task of finding 'a truth which is true for me' (Kierkegaard 1976,5100 / I A 75)
} 
If someone living in the midst of Christianity enters the house of God, the house of the true God, knowing the true conception of God, and now prays but prays untruly, and if someone lives in an idolatrous land but prays with all the passion of the infinite, although his eyes rest upon the image of an idol - where then is there more truth? The one prays truly to God though he worships an idol; the other prays untruly to the true God, and therefore truly worships an idol. (Kierkegaard 2009, p. 169)

Hannay's translation nicely brings out the centrality of adverbial modifiers in the contrast on which this passage hinges: between one who prays untruly and one who prays truly. What makes the difference, I submit, is that the pagan prays in a way that actively takes up the first-person perspective of practical agency. His is not the disinterested stance of empirical self-awareness we illustrated above by reference to Bacon on scientific method. Rather, his is the non-objectifying self-awareness of a finite agent with an 'infinite' - that is, absolute, non-relativized, unqualified interest in his own existence. What distinguishes the true worshipper is his awareness of himself as being at stake in his praying in an unqualified way. The truly praying pagan, as Climacus envisages him, appropriates his received religious practice by praying in a way that is closely aligned with his first-person perspective qua practical agent; he appropriates the practice as a possibility for him. In short, he scores well against the agent's-awareness test.

Now, it is built into Climacus' thought-experiment that the pagan's praying is untrue, by the standards of objective truth, since he mistakenly thinks that in praying to God, he is praying to his idol. So are we to take it that a person can exemplify subjective truth despite being wholly out of touch with reality? If what we mean by 'reality' is whatever can be grasped objectively then it is indeed Climacus' radical view that one can exemplify subjective truth while being out of touch with reality. But we need to step carefully here. Climacus plainly does not think you can exemplify subjective truth if you are out of touch with your own reality as a practical agent. The putative problem with the deluded Christian is precisely that, under an illusion of truly praying, 
he has lost touch with his own reality as a practical agent. Again, everything turns here on the thesis that agent's-awareness is sui generis, irreducible to any form of objective awareness, including empirical self-consciousness. As per Objective Opacity, it is because he takes up a disengaged, third-personal stance towards himself that the putative Christian fails to selfcoincide. ${ }^{27}$ (We may add that, for Climacus, it is by viewing God merely objectively, as an object among objects, that the Christian winds up praying to an idol.)

If this interpretation is right, the critical question becomes whether agent's-awareness is sufficiently robust to constitute a standard of ethical truth. Can this test avoid a suitably modified version of the 'sincere Nazi' style of objection, for example? ${ }^{28}$ A full treatment of these questions would need to engage Kierkegaard's general views of the nature of ethical knowledge and of the demandingness of agent's-awareness. We would need to take into account, for example, his view that fully-fledged agent's-awareness demands Socratic interrogation of one's ethical acculturation and a lived understanding of one's practical possibilities and necessities. ${ }^{29}$ But these are topics for another occasion. All I hope to have shown in this regard is that agent's-awareness is at least more credible qua norm of truth in ethical inquiry than the endeavour to be sincere in what you believe or to practice what you preach, whatever that happens to be.

My main aim, however, has been to show that Kierkegaard's division between objective and subjective truth holds not between different kinds of truth but between different ways in which truth manifests itself as a standard of success in different contexts of inquiry. Let me

\footnotetext{
${ }^{27}$ In the terms of Jonathan Lear's account of Kierkegaardian irony, the putative Christian betrays the aspirations implicit in his own pretense of praying (see Lear 2011, p. 11ff).

28 As we have noted, stock versions of this worry are beside the point. There is no reason to saddle Kierkegaard with the view that a person's sincere assent to Nazi doctrine, for instance, might count as 'a subjective truth': for, Kierkegaard does not conceive of subjective truth as a relationship to doctrines, of whichever stamp. We might still ask, however, about a person who is brought up in a Nazi culture and who appropriates its practices as possibilities 'for her'. In my view, a proper appraisal of this worry would need to look in some detail at actual examples. To assess it as a worry about Kierkegaard, we would also need to take into account other texts which further develop the idea of genuine ethical appropriation through such key notions as irony, earnestness and 'purity of heart' (see also note 17 above).

${ }^{29}$ Thus, it is in the context of a discussion of what constitutes a genuinely ethical form of understanding, for example, that in Works of Love Kierkegaard appeals to the famous example of Luther who 'could do no other' (see Kierkegaard 1995, p. 78).
} 
conclude, then, by explicitly addressing the question: what is the relevant notion of 'manifestation' in the claim that truth manifests itself differently in different contexts of inquiry? How exactly are we to understand Climacus' talk of truth's various ways of 'becoming'?

One way to try to model the relationship between truth and its manifestations is the relationship between a determinable feature and its determinates. We have learned from W. E. Johnson that crimson and scarlet are not kinds of red but determinates of the determinable feature of redness (Johnson 1921). So, on the model of the way redness manifests itself in crimson, scarlet, vermillion and so on, but cannot be defined merely as the disjunctive property of being one or another shade of red, we might try to conceive of truth as determined in different ways in different domains, where the nature of truth itself is such as to transcend its range of determinates. We might then gloss Climacus' account of the contrast between objective and subjective truth by saying that, in this view, objectivity and appropriation are determinates of the determinable feature of self-coincidence. On this proposal, objectivity and appropriation manifest truth in something like the way crimson and scarlet manifest redness.

Notably, contemporary advocates of alethic pluralism have been drawn to the determinable/determinate distinction in trying to model the relationship between 'truthconferring properties' and truth itself. ${ }^{30}$ It has recently been argued that this way of construing truth-conferral will not work, however, because of what might be called the Exclusion Problem. As Crispin Wright frames the issue:

When you really do have an instance of the determinate-determinable relation, the different determinates under the same determinable compete in the same conceptual space: they exclude each other. An object cannot be both crimson and vermilion; the determinates are alternative modes of the determinable: they crowd each other out. (Wright 2013, p. 141)

${ }^{30}$ See Lynch 2011, p. $75 \mathrm{ff}$. 
The Exclusion Problem emerges as a problem for Wright because the sort of alethic pluralism he advocates entails that, in a given domain of discourse, a proposition can simultaneously exemplify not only properties that confer truth within that domain but also ones that, while they do not confer truth within that domain, would do so in other domains. For Wright, therefore, by contrast with the case of scarlet and crimson as determinates of red, the properties that confer truth cannot be mutually exclusive.

Is the Exclusion Problem a problem for Kierkegaard? Plainly not in exactly the way it is for Wright, given the divergence between Wright's propositional conception of truth and Kierkegaard's material conception. But the issue merits further consideration. It amounts to the question whether Kierkegaard thinks an agent can simultaneously exemplify both objectivity and appropriation. There is a strong case that Climacus, at any rate, holds that objectivity and appropriation do indeed crowd each other out; for, he strongly emphasizes the way in which the paths of objective and subjective reflection 'branch off and diverge (Kierkegaard 2009, p. 169). The source of this emphasis is not hard to find: it reflects Climacus' insistence on the basic asymmetry between the disinterested perspective of empirical self-consciousness and the 'infinitely interested' perspective of practical agency.

Against this, it might be objected that Climacus cannot regard objectivity and appropriation as mutually exclusive because of the way he conceives of appropriation in terms of 'double-reflection'. For, the idea of double-reflection, as a certain way of thinking and inquiry, appears to involve the idea of a thinker who takes up both the third-person perspective of objective inquiry and also the first-person person perspective of practical agency. Certainly, the idea of doubly-reflected inquiry is integral to Climacus' view of what it means to strive for agent's-awareness. But it is far from evident that this idea entails that a thinker can simultaneously occupy the third-person perspective of disinterested objectivity and the first-person perspective of unqualified interest in one's own existence. On the contrary, Climacus presents the 'first' and 
'second' moments of double-reflection as temporally distinct parts. ${ }^{31}$ His idea is that, while aiming for objectivity is indeed a proper part of ethical inquiry, this aim is always properly superseded by agent's-awareness. It is precisely because the two perspectives exclude each other that we are to suppose that, in ethical inquiry, the one perspective must ultimately give way to the other.

We may conclude that Kierkegaard's division between objective and subjective truth is not to be construed, in sortal terms, as a distinction among kinds or species of truth but, rather, on the model of the determinates of a determinable feature. On this model, truth itself is the determinable feature of self-coincidence. In empirical inquiry, what confers truth is the objectivity of the (relatively) perspective-free perspective; in ethical contexts, it is agent'sawareness. So construed, and provided we are willing to countenance a non-propositional conception of truth, it seems to me that Kierkegaard's ideas can help to explain the rational pull we may feel on both sides of the problem whether truth is one or many. ${ }^{32}$

\section{References}

Aertsen, Jan 2012, Medieval Philosophy as Transcendental Thought (Leiden: Brill)

Bacon, Francis 2011 [1861], Advancement of Learning, in James Spedding, Robert Ellis \& Douglas Denon Heath (eds.), The Works of Francis Bacon, Vol. VI (Cambridge: Cambridge University Press)

\footnotetext{
31 On the temporal distinctness of the two moments of 'double-reflection', see Watts 2011, p. 539.

${ }^{32}$ Warm thanks, for their help with this paper and critical discussion, to David Batho, Clare Carlisle, Niall Connelly, Fabian Freyenhagen, Steve Gormley, Béatrice Han-Pile, Jim Levine, John Lippitt, Wayne Martin, David McNeill, Vasilis Politis, James Rodwell, Jörg Schaub and Daniel Whiting.
} 
Barns, Jonathan 2011, 'Heidegger in the Cave', in his Method and Metaphysics: Essays in Ancient Philosophy I (Oxford: Oxford University Press)

Broad, William \& Wade, Nicholas 1983, Betrayers of the Truth (New York: Simon \& Schuster) Candlish, Stuart \& Damnjanovic, Nic 2007, ‘A Brief History of Truth’, in Dale Jacquette (ed.) The Philosophy of Logic (Oxford: Elsevier)

Come, Arnold B. 1995, Kierkegaard as Humanist: Discovering My Self(London: McGill-Queen's University Press)

Evans, C. Stephen 1998, 'Realism and Antirealism in Postscript', in G. D. Marino (ed.) The Cambridge Companion to Kierkegaard (Cambridge: Cambridge University Press)

Frege, Gottlob 1977 [1918], 'Thoughts’, in his Logical Investigations (Oxford: Blackwell) Gallop, David 1984, Parmenides of Elea: Fragments (Toronto: University of Toronto Press) Haak, Susan 2005, 'The Unity of Truth and the Plurality of Truths', in Principia 9: pp. 87-109. Hackett, Jeremiah 2013, A Companion to Meister Eckhart (Leiden: Brill) Hegel, G. W. F. 1975, Hegel's Logic, trans. William Wallace (Oxford: Clarendon Press) Heidegger, Martin 2002, The Essence of Truth (London: Continuum) Johnson, W. E. 1921, Logic, Vol. 1 (Cambridge: Cambridge University Press) Kangas, David 1998, 'Kierkegaard as Apophatic Theologian', in Enrahonar 29: pp. 119-123. 2007, 'J. G. Fichte: From Transcendental Ego to Existence', in J. Stewart (ed.) Kierkegaard and his German Contemporaries (London: Ashgate)

Kierkegaard, Søren 1976, Søren Kierkegaard's Journals and Papers Vol. 4, trans. Howard V. Hong \& Edna H. Hong (Indiana: Indiana University Press) 1992, Concluding Unscientific Postscript to the Philosophical Fragments, trans.

Howard V. Hong \& Edna H. Hong (Princeton: Princeton University Press) 1993, Upbuilding Discourses in Various Spirits, trans. Howard V. Hong \& Edna H. Hong (Princeton: Princeton University Press) 
1995 Works of Love, trans. Howard V. Hong \& Edna H. Hong (Princeton:

Princeton University Press)

2009, Concluding Unscientific Postscript, trans. Alastair Hannay (Cambridge:

Cambridge University Press)

Künne, Wolfgang 2008. 'The Modest, or Quantificational, Account of Truth', in Studia

Philosophica Estonica 1: pp. 122-168.

Lear, Jonathan 2011, A Case for Irony (Harvard: Harvard University Press)

Lynch, Michael 2011, Truth as One and Many (Oxford: Oxford University Press)

McDowell, John 2005, 'The True Modesty of an Identity Conception of 'Truth', in International Journal of Philosophical Studies 13: pp. 83-8.

O’Brien, Lucy 2007, Self-Knowing Agents (Oxford: Oxford University Press)

Piety, Marilyn G. 2010, Ways of Knowing: Kierkegaard's Pluralist Epistemology (Texas: Baylor University Press)

Pojman, Louis P. 1983, The Logic of Subjectivity: Kierkegaard's Philosophy of Religion (Alabama: University of Alabama Press)

Posson, David 2010, Review of A. Hannay (trans.) Concluding Unscientific Postscript to the Philosophical Crumbs, in Notre Dame Philosophical Reviews, G. Gutting \& A. F. Gutting (eds) URL $=<$ https://ndpr.nd.edu/news/24269-concluding-unscientific-postscript-to-thephilosophical-crumbs/>

Rae, Murray 1997, Kierkegaard's Vision of the Incarnation: By Faith Transformed (Oxford: Clarendon)

Rescher, Nicholas 1997, Objectivity: The Obligations of Impersonal Reason (Notre Dame: University of Notre Dame Press)Solomon, Robert C. 1987, From Hegel to Existentialism (Oxford: Oxford University Press)

Stern, Robert 1993, 'Does Hegel Hold an Identity Theory of Truth?', in Mind 102: pp. 645-647. Thomas, Mark 2014, 'The Mediation of the Copula as a Fundamental Structure in Schelling's Philosophy', in Schelling-Studien 2: pp. 20-39.Tugendhat, Ernst 1993, 'Heidegger's Idea of 
Truth', in R. Wolin (ed.) The Heidegger Controversy: A Critical Reader (London: MIT

Press)Walsh, Sylvia 1997, ‘Subjectivity Versus Objectivity: Kierkegaard’s Postscript and

Feminist Epistemology' in Céline Léon \& Sylvia Walsh (eds.) Feminist Interpretations of Soren Kierkegaard (Pennsylvania: Pennsylvania State University Press)

Watts, Daniel 2011, 'Kierkegaard and the Search for Self-Knowledge', in European Journal of Philosophy 21: pp. 525-549.

Weil, Simone 2010, Waiting on God (London: Routledge)

Wittgenstein, Ludwig 1974, Philosophical Grammar (Oxford: Blackwell)

Wright, Crispin 2013, ‘A Plurality of Pluralisms', in Nikolaj J. L. L. Pedersen \& Cory D. Wright (eds.) Truth and Pluralism: Current Debates (Oxford: Oxford University Press) 